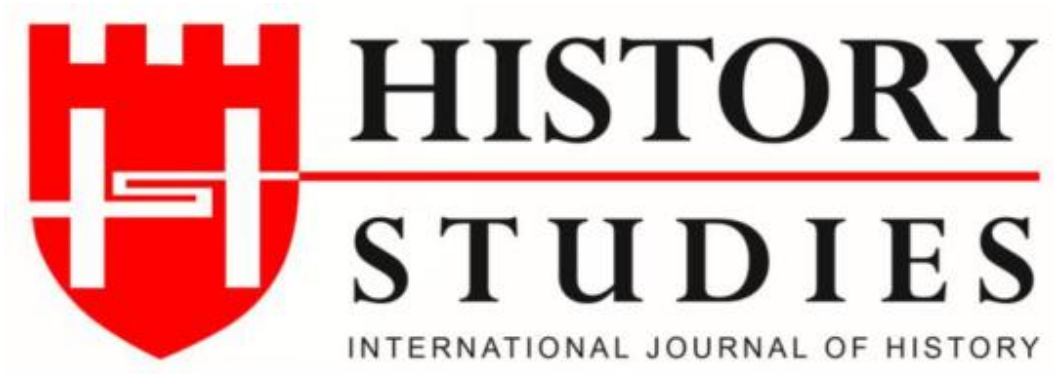

ISSN: 13094173 (Online) 1309 - 4688 (Print)

Volume 10 Issue 10, A Tribute to Prof. Dr. Yilmaz KURT, p. 233-250, December 2018

DOI Number: 10.9737/hist.2018.700

\title{
Sahil Kasabalarında Salgın Hastalıklara Karşı Mücadele: Fatsa Kasabası Örneği (1860-1930)
}

The Struggle against Epidemics in coastal towns: The Town of Fatsa as an Example

(1860-1930)

\author{
Doç. Dr. Tuğrul ÖZCAN \\ (ORCID: 0000-0003-3526-6813) \\ Ordu Üniversitesi - Ordu
}

\begin{abstract}
Öz: XIX. yüzyılda Osmanlı coğrafyasında meydana gelen savaşlar ve göçler, devlet açısından birçok güçlügü beraberinde getirmiştir. Osmanlı demografik yapısının belirlenmesinde oldukça etkili olan bu iki unsur, toplumu derinden etkileyecek olan salgin hastalıklara da ortam hazırlamıştır. Salgın hastalıklarla mücadele, özellikle XIX. yüzyllın son çeyreğinde Osmanlı Devleti'nin içinde bulunduğu buhranı gösterme açısından önemlidir. Bu dönemde gerçekleştirilen deniz ticareti, bir yandan söz konusu mücadeleyi fazlasıyla güçleştirmekte diğer yandan da devletin salgın hastalıklara karşı aldiğ idari tedbirler sebebiyle de sekteye uğrayabilmekteydi. Makalede söz konusu şartlar altında Osmanl Devleti tarafindan salgın hastalıklara karşı yürütülen mücadele ve bunun sonuçları, Karadeniz'de bir iskele özelliğinde bulunan Fatsa kasabası örneği üzerinden ele alınmaya çalışılmıştır.
\end{abstract}

Anahtar Kelimeler: Fatsa Kasabasl, Salgin Hastaliklar, Karantina Uygulamalar

\begin{abstract}
In the 19th century, wars and migrations in the Ottoman geography brought many difficulties for the state. These two elements, which are very effective in determining the demographic structure of the Ottoman Empire, provided an environment for epidemic diseases which would deeply affect the society. The fight against epidemics is particularly important in the last quarter of the nineteenth century in terms of demonstrating the crisis that the Ottoman Empire was in. The maritime trade in this period made the struggle of the state against the diseases quite difficult. At the same time, the administrative measures taken by the state against epidemics could interrupt maritime trade from time to time. In this article, the struggle against epidemic diseases by the Ottoman Empire in these conditions and the results of these struggles were discussed with the example of Fatsa, which is a scaffold town in the Black Sea.
\end{abstract}

Keywords: The Town of Fatsa, Epidemic Diseases, Quarantine Applications

\section{Giriş}

Tarih boyunca gerek bireyler gerekse toplumlar üzerinde kalıcı izler bırakmış olan salgın ve bulaşıcı hastalıkları dikkate almadan geçmişteki bazı olayları ve durumları izaha çalışmak imkânsızdır. Nitekim XIX. yüzyılda veba, kolera, tifüs, sıtma ve çiçek gibi hastalıkların Anadolu'nun hemen her yerinde büyük can kayıplarına yol açtığı ve Osmanlı Devleti'nin sosyal, ekonomik, idari ve askerî yapısını derinden etkilediği bilinmektedir. ${ }^{1}$ Osmanlı Devleti'nin son yüzyılında yapılan hemen her savaş, salgın hastalıklar sebebiyle askerler açısından büyük bir felakete dönüşmüştür. 1828-1829 Osmanlı-Rus, 1853-1856 Kırım, 1877-

\footnotetext{
${ }^{1}$ Mehmet Yaşar Ertaş - Fatma Yıldız, “19. Yüzyıl'da Anadolu'da Sitmanın Görüldüğü Yerler ve Alınan Önlemler”, Tarihsel Süreçte Anadolu'da Sitma, (Edt. Şükran Köse-Çağrı Büke-Fevzi Çakmak-Eren Akçiçek), Gece Kitaplığı Yayınları, Ankara, 2017, s. 223.
} 
1878 Osmanl1-Rus ve 1896 Osmanl1-Yunan savaşlarında; veba ${ }^{2}$, kolera, tifüs ${ }^{3}$, sıtma ${ }^{4}$, çiçek ve frengi $^{5}$ gibi hastalıklar sebebiyle askerlerin önemli bir kısmı ölmüştür. Trablusgarp, Balkan ve I. Dünya savaşlarında da benzer durumlar yaşanmıştır. Özellikle terhis edildikleri dönemlerde karayoluyla evlerine dönen Anadolulu binlerce asker, ister istemez taşıdıkları virüsleri geçtikleri yerlere bulaştırarak birer hastalık kaynağına dönüşmüştür. ${ }^{6}$ Denizyolunu kullanan asker ve muhacirler vasitasıyla da iskele ve limanları bulunan şehir ve kasabalar, kısa sürede bulaşıcı hastalıkların kol gezdiği mekânlar haline gelmişlerdir. ${ }^{7}$ Bu durum 1925-1926 yıllarına ait devlet yıllığına "sâhil klsımda ve münhâl arâzideki nehir vadileriyle göl ve bataklık civârları sitmalı olub frengi dahi münteşî̀" şeklinde yansımıştır. ${ }^{8}$ Bunların dışında, salgın ve bulaşıcı hastalıklara sebep olan diğer bir unsur da ticaret maksadıyla Anadolu kıyılarına gelen yerli ve yabancı ticaret gemileriydi. Bunlar, salgın ve bulaşıcı hastalıkların yaygınlaştığı dönemlerde virüsleri bir iskeleden diğerine taşıyan vasıta görevi görmüşlerdir.

Bir sahil kasabası olması sebebiyle Fatsa, tarihinin hemen her döneminde salgın ve bulaşıcı hastalıklar karşısında savunmasız kalmıştır. Kasabanın etrafında Sülük ve Gaga gölleri, Bolaman ve Elekçi ırmaklarıyla birlikte birçok bataklık mevcuttu. Üstelik arkasında bulunan dă yükseltileri sebebiyle kasabanın iklimi de oldukça nemliydi. ${ }^{9}$ Kasabanın bu özelliklerinden dolayı halk, sık sık salgın ve bulaşıcı hastalıklarla mücadele etmek zorunda

\footnotetext{
${ }^{2}$ Çoğu zaman salgın şeklinde ortaya çıkan veba, tarih boyunca insanlığı en çok tehdit eden bulaşıcı hastalıklardan biridir. Bu hastalık, hemen her dönemde Osmanlı ülkesinde de zuhur etmiştir: Mesut Ayar, "1900 İzmir ve 1901 İstanbul Salgınları Bağlamında Vebanın XX. Yüzyıl Başlarında Osmanlı İmparatorluğu'nda Devam Eden Etkisi”, History Studies, C. 2, S. 2, 2010, s. 173.

${ }^{3}$ Sevilay Özer, "I. Dünya Savaşı'nda Osmanlı Devleti'nde Tifüs”, Belleten, C. LXXX, S.287, Nisan 2016, s. 220.

${ }^{4}$ Sitma, anofel cinsinden dişi sineklerin sokmasıyla insanlara bulaşan ve ateşli nöbetlerle kendini hissettiren bir hastalıktır. Sıtmaya yol açan plazmodium denilen virüsler, sivrisinekler vasıtasıyla insanlara bulaşırlar. Bunların varlıklarını sürdürmeleri; insan-sinek, sinek-insan arasındaki nakil döngüsüne bağlıdır: İnci Hot, Sihhiye Mecmuasına Göre Ülkemizde Bulaşıcı Hastalıklarla Mücadele (1913-1996), İstanbul Üniversitesi Sağlık Bilimleri Enstitüsü, Deontoloji ve Tıp Tarihi Anabilim Dalı, (Yayımlanmamış Doktora Tezi), İstanbul 2001, s. 34; Osmanlı toplumunda sıtma tabiri yerine daha çok humma kullanılmıştır. Sihhatnamelerde bu hastalığa dair hummâ, âteş, âteş-i hummâ, sıcaklık, harâret, terleme, titreme, yanıp-yakılma, teb, tâbişs, lerziş, lerze-nâk, lerzân, teb-lerze, tezelzül, tâb-ı temmuz-ı cihân-sûz, hummâ-yı bi-nevbet, bi-râhat, renciş-i hummâ ve âzürde-i buhrân-ı hummâ gibi kavramlara yer verilmiştir: Mehmet Arslan, "Sıhhatnameler", Türkler, (Edi: Hasan Celal Güzel-Kemal ÇiçekSalim Koca), C. 11, Yeni Türkiye Yayınları, Ankara, 2002, s. 779; Orhan K1lıç, "Eskiçağdan Yeniçağa Sitma", Tarihsel Süreçte Anadolu'da Sitma, (Edt. Şükran Köse-Çağrı Büke-Fevzi Çakmak-Eren Akçiçek), Gece Kitaplığı Yayınları, Ankara, 2017, s. 121.

5 Avrupa ile olan ilişkilerin sınırlılı̆̆ı ve fuhuşun büyük bir suç sayılması gibi sebeplerle XIX. yüzyıla kadar Osmanlı ülkesinde frengi vakasına diğer hastalıklara nazaran daha az rastlanmıştır: Hulûsi Behçet, Frengi Tarihi ve Geçirdiği Evreler [Üniversite Konferansları (1935-1936)], C. 1, İstanbul Üniversitesi Yayınları, İstanbul 1937, s. 256-257; Frengiyi İtalyanlar Fransız hastalığl, Fransızlar Napoliten hastalığl, Almanlar ve İngilizler Fransiz mikrobu, Portekizliler ise Kastilya hastalığı olarak adlandırmışlardır. Hastalığın kaynağı olarak Polonyalılar Almanları, Ruslar Polonyalıları, Araplar İspanya'dan kovulmuş Yahudileri, Hintliler ise Frenkleri (Batı Avrupalılar) suçlamışlardır. İranlılar frengiyi Türk hastalı̆̆g, Türkler de Hristiyan hastalığı olarak görmüşlerdir. Çinliler ise hastalığın dünyaya Portekizlilerden bulaştığına inanmışlardır. Japonlar da bu konuda Çinlileri ve Portekizlileri sorumlu tutmuşlardır: Andrew Nikiforuk, Mahşerin Dördüncü Atlısı (Salgın ve Bulaşıcı Hastalıkların Tarihi), (Çev. Selahattin Erkanl1), İletişim Yayınları, İstanbul 2001, s. 125-126.

${ }^{6}$ İnci Hot, "Türkiye'de Tifüs ile Mücadele", 38. Uluslararası Tip Tarihi Kongresi Bildiri Kitabı, (Edt. Nil Sar1 - Ali Haydar Bayat - Yeşim Ülman - Mary Işın), C. III, Türk Tarih Kurumu Yayınları, Ankara, 2005, s. 1513. Keza II. Dünya Savaşı yıllarında da tifüs vakalarında artış görülmüştür. Bunun üzerine hükümet daha vahim bir tablonun oluşmasını engellemek adına vakit kaybetmeksizin harekete geçerek gerekli önlemleri almıştır. Sevilay Özer, "II. Dünya Savaşı Yıllarında İstanbul'da Tifüs”, Çağdaş Türkiye Tarihi Araştırmaları Dergisi, C. XV, S. 30, Bahar 2015, s. 171-201.

${ }^{7}$ Zafer Toprak, “İstanbul'da Fuhuş ve Zührevi Hastalıklar (1914-1933)”, Tarih ve Toplum, C. 7, S. 39, Mart 1987, s. $39-40$

${ }^{8}$ Türkiye Cumhuriyeti Devlet Yıllı̆̆ı (1925-1926), Matbaa-yı Amire, İstanbul, 1926, s. 376.

${ }^{9}$ BOA, DH.MKT., 825, 22, 8/Z/1321 (25 Şubat 1904); BOA, DH.MKT., 929, 49, 27/Za/1322 (2 Şubat 1905).
} 
kalıyordu. Nitekim XIX. yüzyılın ikinci yarısından itibaren bazı yerel idareciler; bataklıkların kurutulması ve ilaçlanması, yaz aylarında kasaba halkının yaylalara çıkmasının sağlanması, karantina alanlarının oluşturulması, halka ücretsiz ilaç dağıtılması ${ }^{10}$ aşılama yapılması gibi bazı konularda harekete geçtiler.

Salgın ve bulaşıcı hastalıklara karşı verilecek mücadele konusunda öncekine göre Cumhuriyet döneminde daha bilinçli hareket edilmiştir. Bu dönemin devlet adamlarının salgın ve bulaşıcı hastalıklarla mücadelesinin fikrî zeminini 24 Mayıs 1925 tarihli resmî bir kayıtta görmek mümkündür. Buna göre sitmayla mücadele konusunda TBMM görüşmelerinde öngörülen tedbirler şunlardır: Ahalinin sitma hastalı̆̆l ve bundan korunma konularında tam manasıyla bilinçlendirilmesi; okul müfredat programlarında sıtma hastalı̆̆ından korunma yollarına yer verilmesi; afiş, broşür, gazete ve film, ibadethanelerde verilecek vaazlar ve kamu alanlarında uzmanların yapacağı bilgilendirme toplantıları vasitasıyla sitmaya karşı verilen mücadeleye süreklilik kazandırllması; doktorların bir sitma enstitüsünde üç ay süreyle staja tabi tutulmalarl; sitma ile mücadele konusunda Sihhiye ve Muavenet-i İctimaiye Vekâleti'nin daha aktif hale getirilmesi; bataklıkların kurutulması işinin Nafia ve Ziraat Vekâleti'ine bırakılması; askeriyenin sitma ile mücadelesinde Müdafaa-yı Milliye Vekâleti'nin sorumlu tutulması; Hilal-i Ahmer ve diğer kuruluşların sıtma ile mücadelede daha aktif olmalarının să̆lanmast. ${ }^{11}$

Cumhuriyet döneminde Fatsa'da toplum sağlığını tehdit eden sıtmanın dışında önemli diğer bir hastalık da frengiydi. Ancak bu hastalıkla ilgili doğrudan Fatsa'da hizmet veren herhangi bir sağlık kuruluşu mevcut değildi. 1928-1929 yıllarına ait devlet yillı̆̆ından anlaşıldığ 1 üzere Cumhuriyet'in ilk yıllarında frengiyle mücadele etmek üzere Bursa ve Sivas'ta iki merkezî istasyon mevcuttu. Fatsa, bunlardan Sivas istasyonuna bağlı olan Ordu Frengi Mücadele Mintıkası dahilindeydi. Frengiyle mücadele kapsamında bu mıntıkada yürütülecek faaliyetlerin esasını şunlar oluşturmaktaydı: Hükümet ve belediye doktorlarının yaptıkları muayeneler esnasında hastalık belirtisi görülenlerin ücretsiz tedavilerini sağlamak; genelevlerin sihhi şartlara uygunluğunu belirli periyotlar dahilinde denetlemek; köylerdeki frengi hastalarını tespit etmek ve tedavilerini gerçekleştirmek; imkanlar dahilinde bulaşıcı ve salgın hastalıklarla mücadele kapsamında yeni sağlık birimlerinin kurulmasını sağlamak. ${ }^{12}$

\section{A. Bataklıkların Kurutulmasına Yönelik Çalışmalar}

Hastalığın yayılmasında temel etken olan anofel sineklerinin yok edilmesi ve bunların yaşam alanlarını oluşturan bataklıkların ortadan kaldırılması sıtma ile mücadelede oldukça önemlidir. ${ }^{13}$ Sitmanın yaygınlaşmasıyla artan ölüm vakaları, XIX. yüzyılın ortalarından itibaren Osmanlı devlet adamlarında sağlık konusunda ciddi bir zihniyet değişikliği meydana getirmiştir. Bu sayede kentleşmenin de etkisiyle bataklıklara müdahale, devletin öncelikli bir meselesi haline dönüşmüştür. ${ }^{14} 1860$ 'l1 yılların başlarında Kırım ve Kafkasya'dan Osmanlı topraklarına gelen muhacirlerin iskânı, bataklıkların kurutulması fikrinin uygulamaya geçirilmesinde temel bir etkendi. Sazlık alanlara yakın bölgelere yerleştirilen muhacirler arasında çok sayıda ölüm vakasının meydana gelmesi, yetkililerin bataklıkların kurutulması

\footnotetext{
${ }^{10}$ Kemal Özkara, Reşadiye Caddesi, Güneş Ofset Matbaacılık, Fatsa, 2002, s. 6, 16.

${ }^{11}$ BCA, 30-10-00-00-177, 219, 4, 4 (24 May1s 1925).

12 Türkiye Cumhuriyeti Devlet Y1llığı (1828-1829), Matbuat Umum Müdürlüğü, Devlet Matbaası, İstanbul, 1929, s. 160-162.

13 İ. Hot, Sihhiye Mecmuasına Göre Ülkemizde..., s. 37.

${ }^{14}$ İbrahim Serbestoğlu, Bir Taşra Şehrinde Tanzimat ve Modernleşme: Canik Sancă̆l (1863-1865), Huzur Ciltevi, Malatya, 2015, s. 95-96.
} 
konusundaki düşüncelerini kuvvetlendirmiştir. ${ }^{15}$ Bu konudaki itici etkenlerden diğer biri de çeşitli sebeplerle Osmanlı ülkesine gelen yabancıların yapmış oldukları eleştirilerdir. Örneğin Fransız Dr. Barozzi'nin bahsedilen göçler sırasında meydana gelen ölüm vakalarının temel sebebi olarak muhacirlerin sağliklı olmayan yerlere yerleştirilmesini görmesi, Osmanlı devlet adamlarının harekete geçmesinde etkili olmuştur. ${ }^{16}$ 1864'te Fransız seyyah Henry John Van Lennep de Anadolu seyahati sırasında Samsun'da bataklıklar ile bunların yaydığı pis kokudan duyduğu rahatsızlığı her firsatta dile getirmiş ve bu hususta mahalli idarecilerin dikkatini çekmeyi başarmıştır. Seyahatnamesinde Van Lennep, Samsun'daki sıtma vakalarının çok meşhur olduğuna ve gereken tedbirler alınmadığı sürece çevre mahallerde yaşayan çoğu kimsenin bu hastalık sebebiyle hayatını kaybedeceğine özellikle dikkat çekmiştir. ${ }^{17}$ Van Lennep'in bu konudaki haklılığ ilerleyen yıllarda açıkça anlaşılmıştır. Zira 1864, 1867-1868, 1870 yıllarında Fatsa da dâhil olmak üzere Trabzon-Samsun arasında kalan çoğu yer sıtmadan fazlasıyla paylarını almışlardır. ${ }^{18}$

1877-1878 Osmanl1-Rus Savaş1 sonrasında Kafkasya'dan Anadolu'ya yapılan göçlerle birlikte Karadeniz kıyılarına ulaşan binlerce muhacir, tıpkı öncekiler gibi geldikleri yerlerde salgın hastalık, kuraklık ve açlık şartlarında varlıklarını sürdürmek zorunda kalmışlardır. ${ }^{19}$ 1888 ve 1893 yıllarındaki sıtma vakalarında bunların ıstırabı aynı şekilde devam etmiştir. ${ }^{20}$ Ahmet Cevat Güvenkaya'nın notlarına göre Fatsa'ya gelen muhacirlerin neredeyse tamamı, ilk başta kasaba merkezinde ve merkeze yakın köylerde iskân edilmeyi tercih etmişler; böylelikle ister istemez sıtma kaynağının içerisine düşmüşlerdir. ${ }^{21}$ Yerli ahali ise onların aksine kış haricinde Fatsa-Sivas sınırı boyunca uzanan yüksek düzlüklerde yaşamayı kendisi açısından daha uygun görmüştür. ${ }^{22}$

Ağustos 1908 'de Ordu kazasının mutasarrıflığa yükseltilmesi maksadıyla Trabzon İdare Meclisi'ne verilen bir dilekçede Fatsa da dâhil olmak üzere Ordu livası tesisi için öngörülen mücavir alanda geniş ormanlardan, verimli arazilerden, ticarete ve iskâna uygun mekânlardan bahsedilmekteydi. İdari değişikliğin gerçekleştirilmesinin ardından Ordu çevresinde ticari bir canlılık başladı. Buna bağlı olarak meydana gelen nüfus artışı ve kentleşme gibi sebeplerle bataklıkların kurutulması zorunlu hale gelmiştir. Bu durum, Fatsa için de geçerliydi. ${ }^{23}$ III. Ordu Sihhiye ve Emrâz-ı Sâriye Mücâdele Hey'eti Reisi Dr. Tevfik Salim (Sağlam)'in 1914'te hazırladığı rapor bu durumu teyit etmiştir. Söz konusu raporda Fatsa'nın da içinde bulunduğu Tirebolu'dan Canik sancağının batısına kadar tüm sahil boyunca sıtma başta olmak üzere her çeşit salgın hastalığın kol gezdiği belirtilmekteydi. ${ }^{24} \mathrm{Bu}$ yüzden Cumhuriyet’in ilk yıllarında da

\footnotetext{
15 İbrahim Serbestoğlu, "Kırım Savaşı Sonrasında Samsun'da Göç ve Göçmen Sorunu”, Geçmişten Geleceğe Samsun, C. 1, Samsun Büyükşehir Belediyesi Kültür Daire Başkanlığı Yayını, Samsun, 2006, s. 87-90.

${ }^{16}$ Özgür Yılmaz, "1864 Kafkas Göçü Hakkında Bir Rapor”, Mavi Atlas (Gümüşhane Üniversitesi Edebiyat Fakültesi Dergisi, S. 3, 2014, s. 150.

${ }^{17}$ Henry John Van Lennep, Travels in Little-Known Parts of Asia Minor, London, J. Murray by Published, London, 1870, s. 41.

${ }^{18}$ M. Ertaş - F. Yıldız, “19. Yüzyıl'da Anadolu'da Sitmanın...”, s. 235.

${ }^{19}$ Esat Aktaş, Erzurum ve Trabzon Vilayetlerinde Salgın Hastalıklar (1838-1914), Atatürk Üniversitesi Sosyal Bilimler Enstitüsü, (Yayımlanmamıș Doktora Tezi), Erzurum, 2015, s. 274-277; Oktay Özel, "Muhacirler, Yerliler ve Gayrimüslimler, Osmanlı'nın Son Devrinde Orta Karadeniz'de Toplumsal Uyumun Sinırları Üzerine Bazı Gözlemler”, Tarih ve Toplum (Yeni Yaklaşımlar), S. 5, Bahar 2007, s. 97.

${ }^{20}$ M. Ertaş - F. Yıldız, “19. Yüzyıl'da Anadolu'da Sitmanın...”, s. 235.

${ }^{21}$ Ahmet Cevat Güvenkaya, Fatsa'nın Tarihçesine Dair Notlar, (Basım yeri ve tarihi mevcut değil), s. 2.

${ }^{22}$ Trabzon Vilayeti Salnamesi (1904), (Haz. Kudret Emiroğlu), C. XXII, Trabzon İli ve İlçeleri Eğitim, Kültür ve Sosyal Yardımlaşma Vakfi Yayınları, Ankara, 2009, s. 449.

${ }_{23}$ Adnan Yıldız, Osmanlı Belgelerinde Ordu, Ordu Valiliği Yayınları, İstanbul, 2013, s. 31.

${ }^{24}$ İ. Hot, Sihhiye Mecmuasina Göre Ülkemizde ..., s. 39'dan naklen: Tevfik Salim, “333 Senesinde Üçüncü Ordu Mıntıkasında Yapılacak Emrâz-1 Sâriye Mücadelesi Hakkında Proje”, Sihhiye Mecmuası, Y11: 4-5, S. 11-12, 1917, s. $1069-1101$.
} 
salgın hastalıklarla mücadele, devletin öncelikli konularından biri oldu. ${ }^{25}$ Hatta 1924 'te sitma konusunda hazırlattığı bir raporda Sihhiye ve Muavenet-i İctimaiye Vekâleti, durumun vahametini açıkça ortaya koydu. ${ }^{26}$

Bataklıkların 1slahıyla ilgili ilk çalışmalar 1925 'te başlamış ${ }^{27}$ ve TBMM'nin bir kararıyla mücadele kapsamında bataklıkların kurutulması meselesi, Sihhiye ve Muavenet-i Íctimaiye Vekâleti'nin görev alanından çıkarılarak Nafia ve Ziraat Vekâleti'ne bırakılmıştır. ${ }^{28}$ Bu kararla birlikte mesele, meclisin dışında başka toplantı ve ortamlarda da dile getirilmiştir. 2 Eylül 1925 'te I. Millî Türk Tip Kongresi'nde Dr. Refik Saydam, bataklıkların kurutulması, sivrisinek yatağı olan jitlerin ve çeltik sahalarının devlet kontrolüne alınması gibi hususları özellikle gündeme getirmiş ve böylece meseleye yeniden dikkat çekmiştir. ${ }^{29}$ Elekçi ve Bolaman gibi iki ırmak arasında kurulan ve etrafında birçok bataklık ve göl bulunan Fatsa kasabası da bu özelliği itibarıyla bahsedilen meseleye dair proje ve programların bir parçası olarak görülmüştür.

Sıtma vakalarının önünün alınamaması üzerine TBMM'nin 1928'de çıkardığı bir kararla ülke genelinde sitma ile mücadele etmek için heyetler teşkil edildi ve Sihhiye ve Muavenet-i İçtimaiye Vekâleti Bütçesi'nin 480. Sttma Mücadelesi Faslına Tahsisat-ı Munzama İlavesi Hakkında Kanun Tasarısı ile salgın hastalıklar konusunda bir ek bütçe oluşturuldu. ${ }^{30}$ Buna rağmen köylerde doktor bulmak bir yana en basit ilaçların temininde bile güçlük çekilen 1930'lu y1llarda siradan hastalıklardan dolayı insanlar hayatlarını kolayca kaybedebilmekteydiler. Bu yüzden halk, kaynağı sıtma olduğu halde bir türlü sebebini tespit edemediği ölüm vakalarını, birden bire ve sebebi anlaşılmadan manasına gelen hücceten ölüm olarak değerlendirmekteydi. ${ }^{31}$ Tüm bu çabalara rağmen salgın hastalıklarla mücadele kapsamında yürütülen faaliyetler sayesinde Türkiye genelinde bahsedilen yıllar arasında sıtmalı hastaların oranı genelin yaklaşı ancak \% 11 'ine indirilebilmiştir. ${ }^{32}$

\section{B. Yaylalara Çıkmaları Konusunda Ahalinin Teşvik Edilmesi}

Ordu Sıhhiye Müdürü Mehmet Derviş Kuntman'a göre Fatsa da dâhil olmak üzere çevre sahiller tamamen sıtma kaynağıydı. Özellikle yaz aylarında sivrisinekler yüzünden sahil kesimlerinde gece vakti uyumak neredeyse imkânsızdı. Buralarda sıtmanın tehlikeli hemen her türüne rastlamak mümkündü. ${ }^{33} \mathrm{Bu}$ yüzden sahillerde denize girmek, sitmaya yakalanma açısından sahil sakinleri adına büyük bir riskti. Durumun farkında olanlar, denize girmekten

${ }^{25}$ BCA, 30-10-0-0-177, 219, 6, 4 (24 Mayis 1925).

${ }^{26}$ BCA, 30-10-0-0-177, 219, 4 (9 Kasim 1924)

${ }^{27}$ Sağlık Hizmetlerinde 50 Yll, Sağlık ve Sosyal Yardım Bakanlığı Yayınları, Ayyıldız Matbaası, Ankara, 1973, s. 108. 1925 yılında açılan ilk Milli Türk Tıp Kongresinde sıtmalı yerler harita üzerinde gösterilmiştir. Buna göre Türkiye sıtma bakımından iki ayrı bölgeye ayrılmıştır. Bunlardan biri Trakya, Anadolu sahilleri, büyük nehir yatakları ve güneydoğu illeri, diğeri dağlık mıntıkalardaki yüksek platolardır. İlki, sıtma vakalarının daha yoğun olarak görüldüğ̈̈ yerlerdir. İkinci mıntıkada sıtma, daha çok buradaki halkın sıtmanın yoğun olarak görüldüğü yerlere gittiklerinde bu bulaşıcı hastalığa yakalanarak bulundukları mahale getirmeleriyle yayılmıştır. Sevilay Özer, "II. Dünya Savaşı Yıllarında Anadolu'da Sitma", Tarihsel Süreçte Anadolu'da Sitma, (Editör: Şükran Köse ve diğerleri), Gece Kitaplı̆̆1, Ankara 2017, s. 467.

${ }^{28}$ BCA, 30-10-00-00-177, 219, 4, 4 (24 Mayis 1925).

29 İlhan Akçay, "Atatürk Devrinde Sağlı Hizmetleri, IX. Türk Tarih Kongresi (21-25 Eylül 1981), C. III, Türk Tarih Kurumu Yayınları, Ankara, 1989, s. 1854-1857.Sineklerle mücadele sadece sitmanın değil trahom gibi daha pek çok bulaşıcı hastalığın önlenmesi adına da önemlidir. Bkz. Sevilay Özer, "Türkiye'de Trahomla Mücadele", Atatürk Yolu Dergisi, S.54, Bahar 2014, s. 121-152.

${ }^{30}$ BCA, 30-10-0-0-177, 220, 2 (21 Şubat 1928); BCA, 30-18-1-1-28, 29, 6 (9 Nisan 1928).

${ }^{31}$ Hikmet Pala, Ordu Tarihinde Olaylar ve Insanlar, Gece Kitaplığı, Ankara, 2015, s. 245.

${ }^{32}$ İ. Akçay, "Atatürk Devrinde Sağlık Hizmetleri”, s. 1857.

${ }^{33}$ Mehmet Ali Kuntman, Tabur Tabibi Derviş Bey (Tabip Binbaşı Mehmet Derviş Kuntman'ın Harp Hatıraları), Paraf Yayınları, İstanbul, 2011, s. 326. 
özellikle kaçınmış ve çocuklarını bu hususta denetim altında tutmaya çalışmıştır. Ayrıca bazı kimseler, yaz aylarında bataklık ve deniz kıyılarının sık sık ilaçlanmasının da çocukların sağlıklarına zarar vereceğinin farkındaydılar.

Denize girmeyi ve hatta sahilde bulunmayı sağlık açısından oldukça tehlikeli gören bir kısım ebeveyn, denize girip girmediklerini kontrol etmek maksadıyla çocuklarının vücutlarını sabit denen ve suyla temas ettiğinde boyası dağılan bir kalemle işaretlemekteydi. Bu tür uygulamalara hatıratında yer veren bir yazar, çocukların büyük bir kısmının ebeveynlerinden yiyecekleri dayağa rağmen denize girmeye devam ettiklerine dikkat çekmektedir. ${ }^{34}$ Anlaşıldığı üzere sahil ahalisi, bu tür basit önlemlerle, kendi çapında salgın hastalıklarla mücadele etmeye çalışmıştır. Çoğu zaman bu mücadelede başarısız olan ahali, salgın ve bulaşıcı hastalıkların öldürücü etkilerinden korunmak için çareyi yüksek yerlere gitmekte bulmuştur. Hatta bu, artan salgın sıtma vakaları sebebiyle yerel idareciler tarafindan özellikle teşvik edilen bir durum haline gelmiştir.

Yaz aylarında başta kamu çalışanları da olmak üzere Fatsa kasabasında mecbur olmadıkça kimse kalmazdı. Maddi durumu en kötü olanlar bile diğerleriyle birlikte en yakın yaylaya giderlerdi. Fatsa'daki resmî dairelerin bir kısmı, sahilden uzak, havası ve suyu güzel ve rakımı daha yüksek olan Çaltumar köyüne nakledilirdi. Bu yüzden Çaltumar'ın yakınlarında bulunan Yassıtaş, Duayeri, Hatipli ve Bice gibi köyler, yaz aylarında sahilden gelen yüzlerce insana ev sahipliği yaparlardı. ${ }^{35}$ Yaz mevsiminde ve salgın hastalıkların yoğunlaştığı dönemlerde mahkûmlar dahi bahsedilen yerlerin birinde kurulan geçici hapishanelere nakledilmekteydiler. Bunun doğal bir sonucu olarak o dönemde Çaltumar, 250-300 haneden oluşan, derli toplu dükkânları olan, kahvehanesi, mektebi, camisi ve firını bulunan bir merkez durumundaydı. ${ }^{36}$ Yöre ile ilgili bir çalışmasında İlhan Ekinci, benzer durumun Ordu kazası için de geçerli olduğunu ifade etmektedir. Hatta o, sezonluk bu tür değişiklikleri yaylacılık faaliyetleri kapsamında değerlendirir ve bunun da zamanla bir hayat şekline dönüştügünü belirtir. ${ }^{37}$

\section{Bazı Yiyeceklerin Tüketiminden Kaçınılması}

Cumhuriyet'in ilk yıllarında mahalli yetkililerin bulaşıcı ve salgın hastalıklara karşı aldığ 1 tedbirlerden biri de gıda maddelerinin tüketimine ve bireysel temizliğin yaygınlaştırılmasına yönelikti. Bu doğrultuda sağlıklı ortamlarda saklanmayan ve çabuk bozulabilecek yiyeceklerin satış ve tüketimini düzenleyen ve bu konuda halkın bilinçlenmesini sağlayan bazı çalışmalar başlatılmıştır. ${ }^{38}$ 1930'da çıarılan 1593 Sayılı Umumi Hıfzı's-Sihha Kanunu ile gıda maddelerinin tüketimi ve temizlik konularında halkın bilinçlenmesini sağlamak amacıyla kampanyalar düzenlenmiştir. Söz konusu kampanyalar vasıtasıyla özellikle sebze ve meyvelerin sirkeli suyla yıkanması, ev atıkları ve pis su giderlerinin fosseptik çukurlarına bağlanması, meskûn mahallere yakın su birikintilerinin ve bataklıkların yanmamış kireçle izale edilmesi ve bireysel temizlik gibi konularda ahali bilinçlendirilmeye çalışılmıştır. Nitekim öngörülen bu hususlar dâhilinde Fatsa çevresinde de benzer çabaların olduğu, dönemi anlatan hatıratlardan anlaşılmaktadır. Bunların yanında halkın bir kısmı yiyecek konusunda kendi çapında bazı tedbirler almaya çalışmıştır. Örneğin bir kısım halk, sıtma kaynağı olarak gördükleri armut, erik ve şeftali gibi meyvelerle birlikte bazı sebzeleri özellikle yaz aylarında

\footnotetext{
${ }^{34}$ K. Özkara, Reşadiye Caddesi, s. 2-3, 6, 16.

35 K.Özkara, Reşadiye Caddesi, s. 6, 16.

${ }^{36}$ A. C. Güvenkaya, Fatsa'nın Tarihçesine Dair Notlar, s. 1.

${ }^{37}$ İlhan Ekinci, “19. Yüzyılda Bir İskele Kasabası Olan Ordu'nun Bataklık ve Sıtma ile İmtihanı”, Tarihsel Süreçte Anadolu'da Sitma, (Edt. Şükran Köse - Çağrı Büke - Fevzi Çakmak - Eren Akçiçek), Gece Kitaplığı Yayınları, Ankara, 2017, s. 579.

${ }^{38}$ M. Ertaş - F. Yıldız, “19. Yüzyıl’da Anadolu'da Sitmanın...”, s. 242.
} 
tüketmekten kaçınmışlardır. Salgın hastalıklara karşı bir önlem olarak başvurulan bu yol, başka hastalıkların ortaya çıkmasına zemin hazırlamıştır. Çünkü yeterli düzeyde meyve ve sebze tüketemeyen kişilerde vitamin eksikliğinden kaynaklanan bazı hastalıklar ortaya çıkmıştır. Bu durumdan en çok yaşlılar ve çocuklar etkilenmişlerdir. ${ }^{39}$

Bazı insanlar, sık sık yapılan ilaçlamalar sebebiyle zehirli kimyasalların çeşitli vasıtalarla sebze ve meyvelere bulaşabileceğinin farkındaydılar. Aynı zamanda bunlar, meyve ve sebzelerin üzerlerinde hastalık taşıyan virüslerin olabileceğini de biliyorlardı. Bu yüzden bunlar, aile fertlerinin -özellikle çocukların- bu durumdan etkilenmemeleri için büyük bir çaba içerisindeydiler. Ancak çocukların bu konunun ciddiyetine vakıf olmamaları sebebiyle ortaya koydukları duyarsızlık, onların çabalarını çoğu zaman sonuçsuz kılmaktaydı. ${ }^{40}$

\section{Tedaviye Yönelik Çalışmalar}

\section{Tedavi Merkezleri}

Taşrada sıhhi faaliyetlerin yaygınlaştırılması ve arzu edilen düzeyde sonuçların alınması çoğu zaman yalnızca şahsi çabalarla sınırlı kalmaktaydı. Örneğin 1898'de Fatsa'nın belediye tabibi olan Bedros Andon Efendi, bu tür çabalarıyla öne çıkan bir simaydı. Bu özelliğinden dolay1 Bedros Andon Efendi, Meclis-i Maarif-i Tibbiye'nin teklifiyle rütbe-i salise ile taltif edilmiştir. ${ }^{41}$ Bedros Andon Efendi'nin şahsında hassasiyetle yaklaşılan tabiplik mesleği zaman zaman diplomasız bazı kimselerin devlet kontrolünden uzak yerlerde kazanç kapısı olabilmekteydi. Hatta bunlar, sonuçlarını hiç düşünmeden seyyar tabip gibi ahalinin ayağına kadar gitmekte; yasak olmasına rağmen aktarlardan temin ettikleri bitkilerle yaptıkları ilaçları hastalara kullandırabilmekteydiler. ${ }^{42}$ Yeterli sayıda doktor olmaması sebebiyle Fatsa ahalisi, bu tür vakaları normal bir durummuş karşılamaktaydı ${ }^{43}$ Benzer durumlar, Cumhuriyet döneminde de devam etti.

1920'li yıllarda Ordu, Fatsa ve Ünye çevrelerinde yaşayanlara hizmet verebilecek şekilde tam teşekküllü en yakın sağlık kurumu, Samsun'da bulunan belediye hastanesiydi. Fatsalı olup da imkânı dâhilinde Samsun'a gidebilenler, ancak bu hastaneden yararlanabilmekteydiler. Diğerleri ise Fatsa'nın hükümet tabibi Emin Bey'in küçük bir odada ve imkânsızlıklar dâhilinde yaptığı muayene ile yetinmek zorunda kalmaktaydılar. Tedavileri uzun sürecek hastaların bu odada sıhhi hizmetlerinin olması gereken şekilde sağlanması o günkü şartlar dâhilinde mümkün değildi. ${ }^{44}$ Dolayısıyla da Fatsa ahalisi ister istemez kendi başının çaresine bakmak zorunda kalmaktaydı. Örneğin frengiye yakalananlar, ateşte yakılan civa buharı solutulmak suretiyle uygulanana bir yöntemle tedavi edilmekteydiler. Halbuki bu tedavi şekli hasta sağlığı açısından oldukça tehlikeliydi. ${ }^{45}$ Çoğu insan da hastalıklarına kendi bilgi ve tecrübeleri dahilinde aktarlarda deva aramaktaydı. Bakanlar Kurulu'nun 3 Mayıs 1922'te

\footnotetext{
${ }^{39}$ Sıhhiye memurlarının meyve ve sebzelerin yıkanarak tüketilmesi konusundaki ısrarlı çağrılarını çoğu insan, başka şekilde yorumlayarak bunların tüketiminden tamamen vazgeçmişlerdir. Onlar, bu şekilde salgın hastalıklara yakalanmayacaklarını düşünmüşlerdir; K. Özkara, Reşadiye Caddesi, s. 2-3.

${ }^{40}$ K. Özkara, Reşadiye Caddesi, s. 16.

${ }^{41}$ BOA, DH.MKT., 1247, 61, 13/Ra/1326 (15 Nisan 1898).

${ }^{42}$ BOA, DH.MKT., 2088, 49, 08/L/1315 (2 Mart 1898).

${ }^{43}$ BOA, DH.MKT., 2484, 126, 26/M/1319 (15 May1s 1901); BOA, DH.MKT., 2492, 106, 16/S/1319 (4 Haziran 1901).

${ }^{44}$ Türkiye Cumhuriyeti Devlet Yıllı̆̆ (1928-1929), Devlet Matbaas1, İstanbul, 1929, s. 260.

${ }^{45}$ Sağlık Hizmetlerinde $50 \mathrm{Yll}$, s. 91-93.
} 
aldığı bir kararla aktarların satacağı ilaçlar konusunda bir sınırlandırma getirilmesi ahaliyi daha da çıkmaza soktu. ${ }^{46}$

Fatsa'nın genel sıhhi durumu hakkında geçerli bir değerlendirme yapabilmek açısından Samsun hastanesinin istatistik verileri oldukça önemlidir. Çünkü bir zorunluluk olmadığı sürece Fatsa ahalisinin alışverişlerini ve sağlık meselelerini Samsun'da halletmeye çalıştıkları bilinen bir gerçektir. 1930'larda Ordu'ya memleket hastanesi açılmasından sonra dahi Fatsa ahalisi, daha uzak olduğu halde sağlik hizmetleri söz konusu olduğunda tercihlerini Samsun'dan yana kullanmışlardır. ${ }^{47}$ Bu sebepledir ki Cumhuriyet döneminin ilk sıhhiye ve muavenet-i ictimaiye vekillerinden Dr. Refik Saydam'ın, bu göreve gelmeden önceki dönemde Samsun çevresinde yürüttüğü kan tarama kampanyasında analizleri yapılan hastalar arasında Fatsalı birilerinin de bulunması muhtemeldi. Nitekim Refik Saydam'ın başlattığı kampanya sırasında kan analizleri yapılan hastaların yaklaşık yarısında sıtma virüsüne rastlanmıştır. ${ }^{48}$

Frengi ile mücadele kapsamında 1920'li yılların başlarında biri Bursa'da biri de Sivas'ta olmak üzere ülke genelinde hizmet veren iki sağlık istasyonu kurulmuştu. Sivas'taki istasyon, merkez ve Hafik kazalarında hizmet vermekteydi. Fatsa, bu istasyona bağlıydı. ${ }^{49}$ Tevfik Salim (Sağlam)'1n Üçüncü Ordu Mıntıkasında Yapılacak Emrâz-ı Sâriye Mücadelesi Hakkında Proje raporuna göre Canik sancağı da tifüs ile mücadele konusunda öncelikli yerler arasında görülmekteydi. Ancak rapor, istihbarat araçlarının yetersizliği sebebiyle ülkenin her yerinde görülmesine rağmen tifüse dair gerçeği yansıtan rakamlara ulaşmanın zorluğuna dikkat çekmekteydi. ${ }^{50}$ Bununla birlikte frengiye dair istatistik bilgileri, daha düzenli ve gerçekçiydi. Nitekim 1925-1936 yılları arasında Fatsa çevresinde frengiye karşı yürütülen mücadeleye dair istatistiklere göre bu dönemde muayene edilen Orduluların \% 4,8'inde, Ünyelilerin \% 4'ünde ve Fatsalıların ise 2,8'inde frengi bulgularına rastlanmıştır. Buna dair ayrıntılı bilgiler aşağıdaki tabloda (Tablo 1) belirtilmiştir: ${ }^{51}$

\begin{tabular}{llllll}
\hline & & Frengi & & Tedavisi \\
Kazalar & $\begin{array}{l}\text { Muayene } \\
\text { Edilenlerin } \\
\text { Sayıs }\end{array}$ & $\begin{array}{l}\text { Bulgusu } \\
\text { Tespit } \\
\text { Edilenlerin } \\
\text { Say1s1 }\end{array}$ & $\begin{array}{l}\text { Tedavisi } \\
\text { Tamamlananların } \\
\text { Says1 }\end{array}$ & $\begin{array}{l}\text { Kayd1 } \\
\text { Silinenlerin } \\
\text { Sayıs1 }\end{array}$ & $\begin{array}{l}\text { Hükümet } \\
\text { Tabiplerine } \\
\text { Birak1lanların } \\
\text { Sayı1 }\end{array}$ \\
\hline Ordu & 100.556 & 5.147 & 4.219 & 592 & 336 \\
\hline Fatsa & 37.453 & 1.327 & 1.047 & 144 & 136 \\
\hline Ünye & 73.613 & 2.053 & 1.530 & 309 & 214 \\
\hline
\end{tabular}

Tablo 1: Fatsa çevresinde Frengiyle Mücadele Sonuçları (1925-1936)

\footnotetext{
${ }^{46}$ Mehmet Temel, Atatürk Döneminde Bulaşıcı ve Salgın Hastalıklarla Mücadele, Nehir Yayınları, İstanbul, 2008, s. 16-17.

${ }^{47}$ Sağllk konusuyla birlikte diğer konularda da Fatsa ahalisinin Ordu yerine Samsun'u tercih etmesinde iki yerleşim arasındaki ulaşım imkânının daha elverişli olması ile şehrin insanlara sunduğu imkânlar büyük oranda etkili olmuştur. 26 Ağustos 1931'de Ordu Sihhiye Müdürlüğü'ne tayin edilen Mehmet Derviş Kuntman, hatıralarında Ordu Memleket Hastanesi'nin henüz inşaat halinde olduğunu belirtir; M. A. Kuntman, Tabur Tabibi Derviş Bey s. 326.

${ }^{48}$ Bu konuda ayrıntılı bilgi için bkz.; İlhan Akçay, "Atatürk Devrinde Sağlık Hizmetleri, IX. Türk Tarih Kongresi (21-25 Eylül 1981), C. III, Türk Tarih Kurumu Yayınları, Ankara, 1989, s. 1851-1862.

${ }^{49}$ Türkiye Cumhuriyeti Devlet Ylllığ (1928-1929), s. 162-163.

${ }^{50}$ İ. Hot, Sihhiye Mecmuasına Göre Ülkemizde..., s. 130'dan naklen: Tevfik Salim, "333 Senesinde Üçüncü Ordu Mıntıkasında Yapılacak Emrâz-1 Sâriye Mücadelesi Hakkında Proje”, Sihhiye Mecmuası, Yıl: 4-5, S. 11-12, 1917, s. 1069-1101.

${ }^{51}$ İ. Hot, Sihhiye Mecmuasına Göre Ülkemizde..., s. 84.
} 
Özellikle iskelesi olan kasabalar ve şehirler frengi hastalığının yayılması açısından riskli olan yerlerdi. Bu yüzden Cumhuriyet döneminde Dr. Refik Saydam'ın sıhhiye vekilliği döneminde frengiyle mücadele çalışmalarının devlet tarafından üstlenilmesi ve hizmetlerin ülkenin en ücra köşelerine kadar ulaştırılması genel bir politika esası haline getirilmiştir. ${ }^{52}$ 1940'larda da tifüsün yaygınlaşması üzerine ülkede genel aşı uygulamasına geçilmiştir. Aşı talebinin fazlalığı sebebiyle Refik Saydam Hlfzı's-Sihha Enstitüsü'nde bir tifüs laboratuvarı kurulmuştur. Bu laboratuvarda tifüse karşı kullanılan aşıların seri üretimine geçilmiştir. ${ }^{53}$

\section{Aşı Kampanyaları}

1860’11 yıllarda Karadeniz sahillerinde yalnızca çiçek hastalığından dolayı günde 20 kişinin hayatını kaybetmesi Osmanlı hükümetini harekete geçirdi. ${ }^{54}$ Nitekim yetkililer, yurt dışından getirttikleri aşılar ve serumlarla salgın hastalıkların önünü almak istediler. Güçlükler içerisinde yürütülen bu kampanyalar sırasında aşılanan çocuklara dair kayıtlar tutularak Tıbbiye Nezareti'ne gönderildi. ${ }^{55}$ Ancak Osmanlı ülkesinde aşının o dönem itibarıyla üretilememesi, sağlık konusunda yürütülen faaliyetleri çoğu zaman sekteye uğratabilmekteydi.

Osmanlı ülkesinde aşı üretimine XIX. yüzyılın sonlarına doğru İstanbul Telkihhanesi'nde ${ }^{56}$ başlanabildi. Bu telkihhanenin bu y1ldan itibaren Cumhuriyet'in ilk dönemine kadar ülkenin ihtiyaç duyduğu miktarda aşının üretilmesinde büyük hizmeti oldu. ${ }^{57}$ Osmanlı Devleti'nde ilk difteri serumu üretimine ise bundan birkaç y1l sonra -1895'tebaşlanabilmiştir. ${ }^{58}$ Aşıların daha yaygın bir şekilde kullanımına geçilmesi daha geçtir. Örneğin Mart 1916 itibarıyla Ordu, Fatsa, Ünye ve Samsun'da mülteciler arasında ciddi salgın vakaları görülmüştür. Ancak yeterli sayıda aşının bulunamaması sebebiyle salgının önü kısa sürede alınamamıştır. ${ }^{59} \mathrm{Bu}$ durum Cumhuriyet döneminde de devam etmiştir. Çünkü bürokrasinin ağırlığı; zaman zaman sağlık alanındaki hizmetleri ve ihtiyaç duyulan aşı, serum ve ilaçların teminini aksatabilmekteydi. Bir arşiv belgesinden anlaşıldığ 1 üzere Fatsa kaymakamlığ , çiçek hastalığı salgını sebebiyle kazada ihtiyaç duyulan aşıları Sıhhiye Nezareti'nden talep etmiş; ancak durumun aciliyeti sebebiyle Babiâli, bu tür taleplerin doğrudan Trabzon vilayetine yapılması gerektiği hatırlatmasında bulunmuştur. ${ }^{60}$

Çiçek hastalığıyla mücadele, önceki döneme nazaran Cumhuriyet döneminde daha başarılı bir şekilde yürütülmüştür. 1927 yılı içerisinde İstanbul Telkihhanesi'nde 8.210 tüp çiçek aşısı üretilmiş ve $2.180 .114 \mathrm{doz}$ aşı uygulanmıştır. ${ }^{61} 1920^{\prime}$ li yılların sonlarında Fatsa ahalisi için gereken kolera ve tifüs aşları Samsun'daki laboratuvardan temin ediliyordu. Samsun-Fatsa arasındaki mesafenin uzaklığı, ulaşımın elverişsizliği, stoklardaki yetersizlik gibi sebeplerle düzenli bir şekilde ve yeterli sayıda aşı temini konusunda ciddi sıkıntılar

\footnotetext{
52 Türkiye Cumhuriyeti Devlet Yıllığ (1928-1929), s. 153; Sihhiye Mecmuası Fevkalade Nüshası (Dr. Refik Saydam'ın Aziz Hatırasına), C. 17, S. 104, Sıhhat ve İçtimai Muavenet Vekâleti Yayınları, Ulusal Matbaa, Ankara, 1942, s. 84.

${ }^{53}$ Ekrem Kadri Unat, "Osmanlı İmparatorluğunda İnsanın Bulaşıcı Hastalıklarına Karşı Yapılan Koruyucu Aşılar”, Dirim, C. 11-12, S. 53, İstanbul, s. 366-367.

${ }_{54}^{50 A}$ B. AMKT.MHM., 293, 25, 1/\$\$/1280 (1 Subat 1864).

${ }^{55}$ BOA, ID., 35239, 1, 12/Ca/1280 (28 Ekim 1863).

${ }^{56}$ Telkihhane, Osmanlı Devleti'nde çiçek aşısı üretmek üzere kurulan merkeze verilen addır.

${ }^{57} 1934$ 'te Telkihhane, Hıfzı's-Sihha Enstitüsü'ne nakledilmiştir; Sağllk Hizmetlerinde 50 Yıl, s. 84.

${ }^{58}$ İ. Hot, Sihhiye Mecmuasına Göre Ülkemizde..., s. 147.

59 Tevfik Salim Sağlam, Büyük Harpte Üçüncü Orduda Sihhi Hizmete Dair Küçük Bir Hülasa, Askerî Tıbbiye Matbaas1, İstanbul, 1940, s.113.

${ }^{60}$ BOA, DH.MUI., 33, 34, 29/L/1327 (13 Kasim 1909).

${ }^{61}$ Sağlık Hizmetlerinde $50 \mathrm{Yll}$, s. 84.
} 
yaşanıyordu. ${ }^{62} \mathrm{Bu}$ yüzden daha sonraki yıllarda bu konuyla ilgili bazı düzenlemeler yapıldı. 1930'da çıkarılan 1593 sayılı Umumi Hıfzı's-Sıhha Kanunu ile Türkiye genelinde bulaşıcı hastalıklarla tedaviye yönelik mücadele yöntemleri, aşılar ile serumların imali, ithali ve denetlenmesi gibi hususlara da yer verilmişti. Ayrıca kanunla bunların uygulanması için zaman, mekân, mevsim, yaş ve çevre şartlarının tespiti ile antibiyotiklerin üretimi ve dikkatli kullanımı konularında da bazı düzenlemeler getirilmiştir. Bunların dışında yeni doğan her çocuğa ilk dört ay içinde, 30 yaşına kadar herkese ise her beş yılda bir olmak üzere çiçek aşısı yapılması zorunlu olmuştur. Ayrıca çiçek, sıtma, veba, kolera ve tifüs gibi uluslararası bildirimi zorunlu olan salgın hastalıkların yerel idareciler tarafindan telefon ya da telgrafla Sıhhiye ve Muavenet-i İctimaiye Vekâleti'ne seri bir şekilde bildirilmesi de zorunlu kı1ınmıştır. ${ }^{63}$

Umumi Hıfzı's-Sıhha Kanunu gereğince 1931'de Fatsa'da bir hükümet tabibi bulunuyordu. Ayrıca burada hizmet veren iki sıhhiye memurunun istihdam edildiği beş yataklı bir dispanser vardı. ${ }^{64}$ Büyüklerinden duyduklarını kendisiyle yapılan bir mülakatta aktaran Halil İbrahim Aktaş'ın ifadelerine göre Fatsa'da aşılar, Samsun'dan gelen sihhiyeciler tarafından çarşı merkezinde bulunan hamamın önünde yapılıyordu. Aşı uygulamaları ekseriyetle haftalık kurulan pazar günlerine denk getiriliyordu. Aşıların yapılacağı zamanlarda köylere haberler salınıyor, çarşıda belediye tarafından tellallar gezdiriliyor ve özellikle muhtarların bu konuda halkı teşvik etmesi isteniyordu. ${ }^{65}$

\section{3. Ücretsiz Kinin Dağıtımı}

Sitmaya karşı kinin ile mücadele, XVIII. yüzyıldan itibaren Anadolu'da bilinen bir uygulamaydı. İstanbullu Hekim Ali Efendi, Tuhfe-i Aliye adıyla kaleme aldığı bir risalede kininin hammaddesi olan kınakına ${ }^{66}$ bitkisinden ve bu bitkinin sıtmaya karşı etkisinden söz eder. Kinin, Türkiye'de sulfato olarak ancak XIX. yüzyılın başlarında tanındı. Nitekim Maltepe Askeri Hastanesi'nin 1837-1838 dönemi eczane envanterinde kınakına ve sulfato kalemleri de yer almaktayd $1 .{ }^{67}$

Osmanlı Devleti'nde sitmayla mücadele programı dahilinde parasız kinin dağıtımı, 1910'dan itibaren başlamıştır. Fakirlere ve köylülere parasız kinin dağıtımını düzenleyen 29 Mayıs 1913 tarihli Sttmalı Mahallerde Fukara Ahaliye ve Zürrâya Meccanen Kinin Tevzii Hakkında 11 maddelik nizamnâme sıtmayla savaş konusunda atılan önemli bir adımdı. Bu kanuna göre Canik vilayetine 42, Trabzon vilayetine de 30 kilo kinin gönderilmiştir. Fatsa kasabasının kinin ihtiyacı bu iki vilayetten karşılanmışırı. Aynı kapsamda 1917'de kinin tedariki ve satışı ile ilgili genel çerçeveyi çizen bir kanun çıkarılmıştır. ${ }^{68}$

\footnotetext{
${ }^{62}$ Bahsedilen faaliyetler, Mondros Ateşkes Antlaşması'nın imzalanmasın ardından sonlandırılmış̧ır: Sabahattin Özel, Milli Mücadelede Trabzon, Türk Tarih Kurumu Yayınları, Ankara, 1991, s. 23.

63 "Umumi Hifzı's-Sihha Kanunu", s. 405-479.

${ }^{64}$ Sıtkı Çebi, Ordu Hatıraları, Ordu Çevre Koruma Vakfı Kültür Yayınları, Ordu, (Tarihsiz), s. 49

${ }^{65}$ Halil İbrahim Aktaş, 12 Temmuz 2018 Tarihli Mülakat, (Mustafa oğlu, 1940/Fatsa doğumlu, Büfe İşletmecisi).

${ }^{66}$ Kinin, Peru başta olmak üzere Güney Amerika'ya özgü olan Rubiaceae familyasından Cinchona (Kınakına) türlerinin kabuklarında bulunan bir alkaloiddir. Önceleri Cinchona kabuğunun tozu biçiminde kullanılırken 1820'de Fransız eczacılar Pelletier ve Caventou tarafindan saf olarak izole edilmiş ve bundan sonra da saf olarak veya sülfat tuzu biçiminde kullanılmaya başlanmıştır. Kinin, II. Dünya Savaşı sonrasına kadar sıtma tedavisinin tek ilâcı olmuştur. Eski çağlardan beri varlığını sürdürdüğü bilinen sıtma ile mücadelede kınakınanın kullanılması konusunda ilginç ve çelişik pek çok hikâye vardır. Kınakına 17. yüzyıldan itibaren Avrupa'da kullanılmaya başlanmıştır; Gürkan Sert - Emre Dölen, "Osmanlı'dan Cumhuriyet'e Devlet Kinini”, Osmanlı Bilimi Araştırmaları, C. XIV, S. 2, 2013, s. 69, 72.

${ }^{67}$ Fatih Tuğluoğlu, “Türkiye'de Sitma Mücadelesi (1924-1950)”, Türkiye Parazitoloji Dergisi, C. 32, S. 4, 2008, s. 353.

${ }^{68}$ G. Sert - E. Dölen, “Osmanlı'dan Cumhuriyet'e...”, s. 72, 79.
} 
Cumhuriyet döneminde, diğer yerlerin birçoğuna göre Samsun havalisinde sitma ile mücadele daha geç başlamıştır. Kayıtlardan bu mücadelenin 1928 Temmuzunda başladığı anlaşılmaktadır. Bu yüzden bu tarihe kadar söz konusu mahale düzenli ve yeterli miktarlarda kinin gelmiyordu. ${ }^{69} \mathrm{Bu}$ dönemde Sihhat ve İctimai Muavenet Vekâleti tarafindan vilayet sağlık müdürlüklerine $3.729,5 \mathrm{~kg}$; bunların dışında kalan diğer dairelere de $289,6 \mathrm{~kg}$ kinin gönderilmiştir. ${ }^{70} 1930$ 'larda Fatsa kasabasında ihtiyaç duyulan kinin meccanen Samsun'da açılan laboratuvardan temin edilmekteydi. Ancak bunların zamanında ulaştırılması konusunda karşılaşılan aksaklıklar uzun bir süre ortadan kaldırılmadı. ${ }^{71}$

Fatsa esnafından ve eşrafından Halil İbrahim Aktaş, kendisiyle yapılan bir mülakatta büyüklerinin hatıralarından hareketle devlet tarafından dağıtılan kinine dair şunları aktarmıştır: "Biz Fatsa'ya yakın en yüksek tepe olan Çullu'da ikamet etmekteyiz. Bu geçmişte de böyleydi şimdi de böyle. Büyüklerimiz, mümkün olduğu kadar bizleri çarşıya göndermezlerdi. Biz bunun yalnızca gerideki iş güç yüzünden olduğunu düşünürdük. Hatta çok ısrar ettiğimizde "Sitma mı tuttu sizi oturun oturduğunuz yerde." şeklinde azarlanırdık. Sonradan ögrendik ki onlar yalnızca, devletin meccanen kinin dă̆ıttı̆̆ dönemlerde çarşlya giderler ve işlerini görür görmez de dönerlermiş. Sitma için kullanılan kinin onlara, bazen toz bazen de kapsüller şeklinde verilirmiş. Verilen de çoğu zaman yeterli miktarda olmazmış. Bu yüzden tozlu maddeleri karıştırarak kinin diye sahte karışımlar yaparak bunları satan çok sayıda sahtekâr türemiş. Kininin sahte olup olmadığı bazı kafa karışıklıklarına yol açtığından çeşitli bitkilerin kurutulmastyla yapılan kocakarı ilaçlarlyla sıtmaya karşı koyulduğu da olurmuş. Ancak bundan ne kadar fayda görüldü̈̆̈̈ de belli değilmiş.,"72

\section{E. Karantina, Tecrit ve Tebhir Uygulamaları}

Bulaşıcı ve salgın hastalıklardan birinin görüldüğü bir ülkeye ait taşıma aracında bulunan yolcuların, hayvanların veya eşyaların gidilen ülkenin sakinleriyle temas ettirilmeden önce tedbir maksadiyla belirli bir noktada veya gemilerinde bekletilmesiyle gerçekleştirilen uygulamalara karantina denir. ${ }^{73}$ İlk defa 1831 'de başlayan bu uygulama, Osmanlı sağlık tarihi açısından önemlidir. Kolera salgınları sebebiyle 1866 'da İstanbul'da toplanan Uluslararası Sağlık Konferansı da bulaşıcı ve salgın hastalıklar konusunda Osmanlı ülkesinde atılan diğer önemli bir adımdır. ${ }^{74}$

Osmanlı Devleti'nde XVIII. yüzyılın sonlarından itibaren liman ve iskeleler çevresinde tahaffuzhane adıyla bu hizmeti veren birçok sağlık kuruluşu mevcuttu. Bunlar, başka bir ülke ya da şehirden gelen insanların toplu bir şekilde bir süreliğine misafir edilip sağlık kontrollerinin ve temizliklerinin yapıldığ 1 binalardan müteşekkildi. Tahaffuzhanelerde yapılan kontrollerden sonra yalnızca, hastalık taşımadığına kanaat getirilenlerin gümrükten geçişlerine müsaade edilmekteydi. ${ }^{75}$

\footnotetext{
${ }^{69}$ G. Sert - E. Dölen, “Osmanlı'dan Cumhuriyet'e...”, s. 79'dan naklen: Enver, Samsun Mintıkasında Sitma Mücadele Faaliyeti”, Sihhiye Mecmuası, C.5, S. 31-32, 1922, s. 1447.

${ }^{70}$ Türkiye Cumhuriyeti Devlet Ylllığ (1928-1929), s. 167-169.

${ }^{71}$ Bahsedilen faaliyetler, Mondros Ateşkes Antlaşması'nın imzalanmasın ardından sonlandırılmıştır: Sabahattin Özel, Milli Mücadelede Trabzon, Türk Tarih Kurumu Yayınları, Ankara, 1991, s. 23.

${ }^{72}$ Halil İbrahim Aktaş, 12 Temmuz 2018 Tarihli Mülakat, (Mustafa oğlu, 1940/Fatsa doğumlu, Büfe İşletmecisi).

73 Osmanlı Devleti'nde karantina hizmeti verilen yerlere tahaffuzhane adı verilmektedir: Nuran Yıldırım, “Tanzimat'tan Cumhuriyet'e Koruyucu Sağlık Uygulamaları”, Tanzimat'tan Cumhuriyet'e Türkiye Ansiklopedisi, C. 5, İletişim Yayınları, İstanbul, 1985, s. 1322, 1324.

${ }^{74}$ Bedi N. Şehsuvaroğlu, "Tarihi Kolera Salgınları ve Osmanlı Türkleri”, İstanbul Tıp Fakültesi Mecmuası, C. 17, S. 2, İstanbul, 1954, s. 292-293.

${ }_{75}$ İbrahim Başağaoğlu, "XX. Asrın başlarında Sinop'ta Görülen Bulaşıcı Hastalıklar”, Osmanlı'da Salgın Hastalıklarla Mücadele, Çamlıca Basım-Yayın, İstanbul, 2015, s. 155.
} 
Osmanlı ülkesinin diğer yerlerinde de olduğu gibi Karadeniz'in muhtelif sahil kasabalarında karantina uygulanmasına rağmen 1878 yılı itibarıyla Fatsa'da karantina memuru mevcut değildi. ${ }^{76}$ Döneme ait arşiv belgelerinden anlaşıldığı üzere 1894 yılının başlarından itibaren Sinop hariç Canik sancağının kıyılarının neredeyse tamamı karantinaya alınmıştır. Kolera sebebiyle uygulanan karantina sırasında posta naklinde görevli karakol istimbotunun reisi Uzluoğlu Ali Efendi, sahillerde izinsiz deniz vasıtalarının dolaşmasını engelleyerek büyük bir görev ifa etmiştir. ${ }^{77}$ Ali Efendi'nin de katkılarıyla Canik sancağı dâhilinde koleranın büyük oranda kontrol altına alınması üzerine 1894 yazında Fatsa-Sinop arasında kalan yerlerdeki karantina uygulamaları haftada bir güne indirilmiştir. ${ }^{78}$

1905 'te Samsun limanında görevli istimbotlarda bulunan sandallar, Fatsa iskelesine sevk edilerek burada karantina hizmetine verilmiştir. ${ }^{79}$ Ayrıca salgın vakalarının arttı̆̆ dönemlerde devlet, hastalığın seyrini takip etmek maksadiyla sahiller boyunca gezen bir gemi görevlendirmiştir. 3 Kasım 1908 tarihli bir arşiv belgesinden anlaşıldığı üzere Fatsa da dâhil olmak üzere birçok kıyı kasabasının sahilini Karantina İdaresi, gözetleme istimbotları aracılığıyla denetimi altında tutmaya çalışmıştır. ${ }^{80}$ Salgın vakaları sebebiyle 1910 'da Trabzon limanı, başta olmak üzere Ordu, Fatsa ve Ünye gibi iskeleleri bulunan yerlere hiçbir şüpheli geminin yanaşmasına müsaade edilmemiştir. ${ }^{81}$

Balkan Savaşları sırasında tifüse yakalanıp iyileştikten sonra III. Ordu Sihhiye ve Emrâz-l Sâriye Mücâdele Hey'eti Reisliği'ne atanan Dr. Tevfik Salim (Sağlam), Ankara, Sivas, Erzurum ve Trabzon vilayetleri ile Kayseri, Niğde ve Canik sancaklarında bulunan her kaza ve nahiye merkezine birer tebhirhane ile buğu sandığı yapılması ve gerekirse karantina bölgeleri oluşturulması için yoğun çaba sarf etmiştir. Nihayet onun da çabalarıyla yapılması hedeflenen 177 tebhirhaneden 148 'i on ay içinde faaliyete geçirilmiştir. Ayrıca tifüs vakası görüldüğünde; hastalığın başladığı günden 12 gün evvel hasta kişinin nerede bulunduğu ve kimlerle temas ettiği sağlık memurları ve kaza tabipleri tarafından sıkıca takibe alınarak gerektiğinde müdahale edilmiştir. ${ }^{82}$

I. Dünya Savaşı sırasında yaşanan salgınlar sebebiyle sivillere yönelik sağlık hizmetleri de Ordu Sihhiye Riyaseti'nin uhdesine verilmiştir. ${ }^{83}$ Ordu, Fatsa ve Ünye'de birer muhacir hastanesinin kurulması da bu vesileyle olmuştur. Bu hastanelerin bir bölümü tecrithane ve tebhirhane olarak kullanılmıştır. ${ }^{84}$ Ayrıca Sıhhiye Nezareti'ne bağlı olmak üzere bahsedilen yerlerde özellikle sıtmayla mücadele etmek amacıyla merkezi Samsun'da bulunan enstitü için

\footnotetext{
76 BOA, DH.MKT., 238, 13, 14/Za/1311 (19 Mayıs 1894); Trabzon Vilayet Salnamesi (1878), s. 82.

${ }^{77}$ BOA, DH.MKT., 303, 35, 04/Ca/1312 (3 Kasim 1894); BOA, DH.MKT., 240, 32, 18/Za/1311 (23 May1s 1894); BOA, Yıldı Sadaret Hususi Maruzat Evrakı(Y.A.HUS.), 304, 31, 24/Ca/1312 (3 Kasım 1894); Kuzeydoğu Anadolu sahillerinde yaşanan kolera salgınları konusunda ayrıntılı bilgi için bkz.; Nedim İpek, "Trabzon'da Kolera (1892-1895), Trabzon ve Çevresi Uluslararası Tarih-Dil-Edebiyat Sempozyumu (3- 5 Mayıs 2001), C. 1, Trabzon Valiliği Yayınları, Trabzon, 2002, s. 399-411.

${ }^{78}$ BOA, A. JMKT.MHM., 553, 9, 27/M/1312 (31 Temmuz 1894).

${ }^{79}$ BOA, DH.TMIK.M., 206, 38, 27/B/1323 (27 Eylül 1905).

${ }^{80}$ BOA, DH.MKT., 2621, 16, 07/N/1326 (3 Ekim 1908).

${ }^{81}$ İbrahim Dizman, Ordu'nun XX. Yüzyıll, Ordu Belediyesi Yayınları, Ordu, 2006, s. 21.

82 İ. Hot, "Türkiye'de Tifüs ile Mücadele", s. 1514.

${ }^{83}$ Hikmet Özdemir, Salgın Hastalıklardan Ölümler (1914-1918), Türk Tarih Kurumu Yayınları, Ankara, 2005, s. 300.

${ }^{84}$ BOA, DH, ŞFR, 84/28, 9 Şubat 1334 (9 Şubat 1918); Nedim İpek, Imparatorluktan Ulus Devlete Göçler, Serander Yayınları, Trabzon, 2006, s. 164.
} 
seyyar laboratuvarlar açılmıştır. ${ }^{85}$ Bu laboratuvarlarda birer doktor ve sağlık memuru istihdam edilmeye çalışılmıştır. ${ }^{86}$

Fatsa meydanının arka tarafında Reşadiye Caddesi'ne yaklaşık yüz metre mesafede bulunan hamam ${ }^{87}$ zaman zaman tebhirhane ${ }^{88}$ olarak da kullanılmıştır. Fatsa'da evleri dışında insanların temizlenebileceği kapalı tek yer olan bu hamam, ihtiyaç duyulduğunda bakıma muhtaç kimsesizlerin haşereden ve mikroptan izale edilmek için temizlendiği bir mekân olarak da hizmet vermiştir. Burada kimsesizlerin çamaşırları yüksek sıcaklıklarda kaynatılarak ve ilaçlanarak mikroplardan arındırılırdı. ${ }^{89}$

\section{F. Salgın hastalıklara Karşı Yürütülen Mücadelenin Sonuçları}

Osmanlı Devleti'nin son dönemlerinde salgın hastalıklarla mücadelesi, çıkarılan bir kaç tüzük ve yasa, ücretsiz kinin dağıtımı, ilaç satışını düzenleyen bazı esasların tespiti ile sınırlı kalmıştır. Bu yüzden salgın ve bulaşıcı hastalıklarla daha kapsamlı ve gerçekçi mücadele, büyük ölçüde Osmanlı Devleti'nden Türkiye Cumhuriyeti'ne miras kalmıştır. Özellikle I. Dünya Savaşı sırasında ve sonrasında meydana gelen nüfus hareketliliği ile birlikte kol gezen salgın ve bulaşıcı hastalıklar, yetkilileri çaresiz bırakmıștır. Resmî kaynaklara göre; Fatsa'nın da içinde bulunduğu III. Ordu'nun görev mıntıkasında Mart 1915 - Eylül 1918 arasında 19.619 kişi salgın ve bulaşıcı hastalıklara yakalanmış; bunlardan 7.310'u hayatını kaybetmiştir. Farklı bir kaynakta da I. Dünya Savaşı boyunca bu ordunun görev mahallinde 93.000 kişinin bulaşıcı ve salgın hastalıklara yakalandığı ve bunların 26.322 'sinin hayatını kaybettiği belirtilir. ${ }^{90} \mathrm{Bu}$ tür vakalar, Rus ordusunda da görülmüştür. 1915'te Fatsa-Perşembe arasında konuşlanan Rus torpidolarındaki çoğu mürettebat, bu tür vakalara maruz kalmıştır. Hastalık onlara, yardım maksadıyla kıyıdan yanlarına gelen işbirlikçilerinden bulaşmıştır. ${ }^{91}$

Aralık 1916 itibarıyla 18.000'i Ünye'de, 1.500'ü de Fatsa'da olmak üzere Samsun havalisinde yaklaşık 85.000 muhacir vard. Muhacirin İdaresi'nin girişimleriyle bunlar için Fatsa, Ünye, Terme ve Çarşamba'da birer sağlık istasyonu tesis edildi. Bazı yerlerde de tecrithane ve tebhirhane hizmete sokuldu. ${ }^{92}$

Alınan tedbirlere rağmen I. Dünya Savaşı boyunca Ordu'dan Sinop, İnebolu, Amasya ve Çorum taraflarına giden ${ }^{93}$ muhacirlerin takriben \% 30’u bulaşıcı ve salgın hastalıklar sebebiyle hayatlarını kaybetti ${ }^{94}$. Muhacirlerin içinde bulundukları durumu Hollandalı tarihçi Eric Jan Zürcher eserinde şu şekilde özetlemiştir: "Tifüse yol açan bit yumurtaları, elbise ve eşyalarla

${ }^{85}$ Sitma ve bulaşıcı hastalıklarla mücadele kapsamında birçok ilde 31 adet seyyar laboratuvar açılmıştır: BCA, 3018-1-1-16, 73, 3 (15 Kasim 1925).

${ }^{86}$ Bahsedilen faaliyetler, Mondros Ateşkes Antlaşması'nın imzalanmasın ardından sonlandırılmıştır: Sabahattin Özel, Milli Mücadelede Trabzon, Türk Tarih Kurumu Yayınları, Ankara, 1991, s. 23.

${ }^{87} 2000$ 'li yıllara kadar Fatsalılara hizmet veren bu hamam, daha sonra balıkhane olarak kullanılmaya başlandı. Birkaç yıl sonra Fatsa Belediyesi'nin peyzaj çalışmaları sebebiyle yıkılan hamamın yeri, yeşil alana dönüştürüldü.

${ }^{88}$ Tebhirhane, giysi ve eşyalarla ev ve işyeri gibi mekânları her türlü haşereden ve pislikten arındırmak amacıyla kurulan temizlik istasyonu ya da temizlik evi demektir. Salgın ve bulaşıcı hastalıkların hüküm sürdüğü dönemlerde onlara ait bulguların görüldüğ̈̈ yerde bulunan eşyaların ve giysilerin dezenfekte işi tebhirhanelerde yapılırdı. Osmanlı Devleti'nde karantina hizmeti verilen yerlere de tahaffuzhane adı verilmektedir: N. Yıldırım, “Tanzimat'tan Cumhuriyet'e...", s. 1324-1325.

${ }^{89}$ Halil İbrahim Aktaş, 12 Temmuz 2018 Tarihli Mülakat, (Mustafa oğlu, 1940/Fatsa doğumlu, Büfe İşletmecisi).

${ }^{90}$ T. S. Sağlam, Büyük Harpte Üçüncü Orduda ..., s. 78; H. Özdemir, Salgın Hastalıklardan ..., 199.

${ }^{91}$ BOA, DH.ŞFR., 488, 31, 26 Ağustos 1331 (8 Eylül 1915).

${ }_{92}$ Azmi Süslü, Ermeniler ve 1915 Tehcir Olayl, Ankara, Yüzüncü Yı1 Üniversitesi Yayınları, 1990, s. 125-127.

${ }^{93}$ BOA, DH, ŞFR, 70/87, 29/S/1335 (25 Ekim 1916); Nedim İpek, Imparatorluktan Ulus Devlete Göçler, Serander Yayınları, Trabzon, 2006, s. 136; Muzaffer Lermioğlu, Akçaabat-Akçaabat Tarihi ve Birinci Genel Savaş-Hicret Hatıraları, Kardeşler Basımevi, İstanbul 1949, s. 259.

${ }^{94}$ Sabahattin Özel, Milli Mücadelede Trabzon, Türk Tarih Kurumu Yayınları, Ankara, 1991, s. 23. 
bir yerden başka bir yere taşınıyordu. Bunun bedelini savaş bölgelerinden daha güvenli yerlere gitmek zorunda kalan muhacirler, Sevk ve İskân Kanunu'na dâhil edilen Ermeniler ve güzergâh üzerinde bulunan ahali ödüyordu." 95 Sevk ve İskân Kanunu kapsamında değerlendirilen bir kısım Ermeni, salgın hastalıklar ve ağır iklim koşulları sebebiyle çocuklarını güvendikleri Müslüman komşularına bırakarak bulundukları yerleri terk etmek zorunda kaliyordu. ${ }^{96}$

5 Mayıs 1917'de, Ordu Kumandan Vekili Fevzi Paşa, Karadeniz sahil mıntıkasını teftişi sırasında Dâhiliye Nezareti'ne gönderdiği telgrafında muhacirlerin genel durumunu şu şekilde rapor etmiştir: "Samsun mıntıkasının teftişinde muhacirleri, pek elem-nâk bir vaziyette gördüm. Yaptırdığım sihhi teftişler esnasında liva merkezi, kasabalar ve köylerdeki halkın askerî sevkiyatlar sebebiyle her an için bulaşıcı hastalıklara maruz kaldıklarına tanık oldum. Muhacirler çoluk-çocuk, genç-yaşll, kadın-erkek yollarda perişan bir vaziyette kalvyorlar. Tabiattyla haklarında gerekli shhhi önlemler tam manasiyla da tatbik olunamiyor. Bunlar, karışık bir surette köy ve kasabalara taksim edildikçe gittikleri yerlere de peşlerinden salgın hastalıkların amansız tohumlarını pervasızca saçıyorlar. "97

Ordu çevresiyle ilgili birçok çalışması bulunan İbrahim Dizman, bir eserinde I. Dünya Savaşı sırasında Trabzon'dan hareketle Ordu'ya gelen muhacirlerin karşılaştıkları sıkıntıları bir hatıraya dayanarak: "Yolculuk sirasında hastalanıp yürüyemez hale gelenler, muhacir kafilesi için büyük bir dertti. Kafilenin, hastaları bırakacakları bir yer olmadığ gibi onlarla birlikte kalıp iyileşmelerini beklemeye de durumları müsait değildi. Bu sebeple hastalar, ıstıraplarını kimseye belli etmemeye çalışlyorlar, kafileyi takipten geri kalmak istemiyorlard. Daha fazla dayanamayı hayatların kaybedenler, yolun kenarlarında kazılan mezarlara kefensiz bir şekilde gömülüyorlardl. Kafile ölüm vakaları sebebiyle meydana gelen kısa duraklamalardan sonra topră̆a terk ettikleri yakınlarına ă̆ıt düzen kadınları dinleye dinleye yoluna devam ediyordu. Yol boyunca yüzlerce garip mezarı, bir zincir gibi uzanıp gidiyordu." şeklinde ifadeleriyle özetlemektedir. ${ }^{98}$

I. Dünya Savaşı'ndan sonraki dönemde salgın hastalıklar sebebiyle meydana gelen ölüm vakalarında kısmi bir azalma yaşanmıştır. ${ }^{99}$ Ancak mübadele döneminde Samsun'a gelen mübadillerden günde yaklaşık 100'ü hayatını kaybetmiştir. Bunların yarıya yakını çocuklardan meydana gelmekteydi. ${ }^{100}$

Cumhuriyet'in ilk yıllarında kamu alanlarına yapılan yatırımlar ve ülkenin kalkındırılması için ortaya konulan çabalar sayesinde Türkiye'de kısmen normal bir hayat akışı sağlanmıştır. Buna rağmen 1930'lu yıllarda salgın ve bulaşıcı hastalıklar, Fatsa'nın yerli ahalisi ile muhacirlerin komşuluk ilişkilerini olumsuz etkilemiştir. Fatsa'da dondurmacılık yapan ve aslen bir muhacir olan Şevki Efendi hakkında bulaşıcı hastalık taşıdığına dair çıkan dedikodular, iki unsur arasındaki komşuluk ilişkilerinden ticarete kadar birçok alanı olumsuz etkilemiştir. Bir kısım muhacir, yerli ahalinin tutumunu kendilerine yönelik bir boykot olarak algılamıştır. ${ }^{101}$

\footnotetext{
95 Eric Jan Zürcher, "Between Death and Desertion: The Experience of The Ottoman Soldier in World War I", Turcica, Volume: 28, 1996, s. 244.

96 T. S. Sağlam, Büyük Harpte Üçüncü Orduda ..., s. 53.

97 T. S. Sağlam, Büyük Harpte Üçüncü Orduda ..., s. 53.

${ }^{98}$ İ. Dizman, Denize Düşen Dă̆g: Ordu, s. 90.

${ }^{99}$ Meclis-i Ayan Zabıt Ceridesi, III/II, Türkiye Büyük Millet Meclisi Basımevi, Ankara, 1990, s. 212-213.

${ }^{100}$ Rüştü Demirel, "Yunanistan'dan Anadolu'ya Gelen Türkler (Nüfus Mübadelesi)", Rüştü Demirel'in Mesleğe ve Hayata Dair Biriktirdikleri, Ordu Serbest Muhasebeci Mali Müşavirler Odası (SMMMO) Yayınları, Samsun, 2018, s. 133.

${ }^{101}$ K. Özkara, Reşadiye Caddesi, s. 15.
} 


\section{Sonuç}

Osmanlılar döneminde ülke genelinde olduğu gibi Fatsa'da da salgın hastalıklarla mücadele konusunda XIX. yüzyılın ikinci yarısından itibaren birçok tedbir alınmasına ve merkezî idarenin bu konudaki hassasiyetine rağmen başarılı olunamadığı açıç̧a ortadadır. Çünkü Sıhhiye Nezareti'nin İstanbul'dan başlattığı bir uygulamanın vilayetlere, vilayetlerden sancaklara, sancaklardan kazalara ve kazalardan da köylere ulaşması aşamasında birçok aksaklıklar yaşanmaktaydı. Hatta merkezî idare tarafindan verilen çoğu talimat, uygulamaya geçirilemeden yalnızca taşrayla yapılan bir yazışma olarak kalmaktaydı. Zira salgın ve bulaşıcı hastalıklarla mücadele için gereken her türlü malzemenin ve ilacın en kısa zamanda yerine ulaştırılması konusunda ortaya çıkan aksaklıklar merkezî idareyi başarısız kılıyordu. Bu yüzden salgın hastalıklarla mücadele, daha ziyade ahalinin kendi kendine almaya çalıştığı basit tedbirlerle ve mahalli hükümetin imkânsılıklar dahilinde yürüttügü uygulamalarla sınırlı kalıyordu.

Vakaların, ekseriyetle savaş ya da göç dönemlerinde cereyan etmesi, taşra yöneticilerini salgınlara karşı kıt imkânlarla mücadeleye sevk etmekteydi. Bu durum, yerel idarecilerin şevkini kırılmasına ve salgın hastalıklarla mücadelelerinin çoğu zaman kâğıt üzerinde kalmasına yol açmıştır. Aynı zamanda sağlık personeli konusunda yaşanan yetersizlik de salgın hastalıklara karşı yerinde ve zamanında önlemler alınmasını engellemiştir.

Öncekine nispeten Cumhuriyet döneminde salgın ve bulaşıcı hastalıklarla mücadele konusunda ülke genelinde kayda değer bir gelişme yaşanmıştır. Fatsa kasabası, kısmi de olsa bu iyileşmeden payını almıştır. Ancak 1923-1929 yılları arasında kinin tedarikinin zorluğu, haşerelere karşı kullanılacak ilaçların bulunmaması, bataklıkların mevcudiyeti, sağlık personeli yetersizliği gibi unsurlar sebebiyle söz konusu mücadelede zaman zaman aksaklıklar da yaşanmıştır.

Bulaşıcı ve salgın hastalıkların yaygınlaşması ve buna bağlı olarak muhacir ve mübadiller arasında artan ölüm vakaları sebebiyle zamanla, politikası üzerinden gerek Osmanlı Devleti’ni gerekse Türkiye Cumhuriyeti'ni kusurlu bulan bir zihniyet de ortaya çıkmıştır. Bu zihniyete sahip olanlar, salgın vakalarının oldukça tehlikeli boyutlara ulaştığı dönemlerde, muhacirlerin ve mübadillerin elverişsiz yerlere iskân edildiklerini ileri sürmektedirler. Oysaki söz konusu unsurlar, her iki tarafi ırmak olan ve etrafında bataklıklar ile göller bulunan Fatsa kasabasının merkezinde ya da buraya yakın yerlerde özellikle iskân edilmek istemişler ve bu durumu da ileri gelenleri vasıtasıyla resmî makamlara defaten bildirmişlerdir.

\section{Kaynakça}

Akçay, İlhan, "Atatürk Devrinde Sağlık Hizmetleri”, IX. Türk Tarih Kongresi (21-25 Eylül 1981), C. III, Türk Tarih Kurumu Yayınları, Ankara, 1989, s. 1851-1862.

Aktaş, Esat, Erzurum ve Trabzon Vilayetlerinde Salgın Hastalıklar (1838-1914), Atatürk Üniversitesi Sosyal Bilimler Enstitüsü, (Yayımlanmamış Doktora Tezi), Erzurum, 2015.

Aktaş, Halil İbrahim, 12 Temmuz 2018 Tarihli Mülakat, (Mustafa oğlu, 1940/Fatsa doğumlu, Büfe İşletmecisi).

Arslan, Mehmet, "Sihhatnameler", Türkler, (Edt: Hasan Celal Güzel-Kemal Çiçek- Salim Koca), C. 11, Yeni Türkiye Yayınları, Ankara, 2002, s. 776-790.

Ayar, Mesut, "1900 İzmir ve 1901 İstanbul Salgınları Bağlamında Vebanın XX. Yüzyıl Başlarında Osmanlı İmparatorluğu'nda Devam Eden Etkisi”, History Studies, C. 2, S. 2, 2010, s. 173-188. 
Başağaoğlu, İbrahim, "XX. Asrın başlarında Sinop’ta Görülen Bulaşıcı Hastalıklar”, Osmanlı'da Salgın Hastalıklarla Mücadele, Çamlıca Basım-Yayın, İstanbul, 2015, s. 151-163.

Başbakanlık Cumhuriyet Arşivi (BCA): 30-10-0-0-177, 219, 4 (9 Kasım 1924); 30-10-0-0177, 219, 4, 6 (24 Mayıs 1925); 30-10-0-0-177, 220, 2, (21 Şubat 1928); 30-10-0-0, 177, 221, 11 (16 Eylül 1936); 30-18-1-1-28, 29, 6 (9 Nisan 1928).

Başbakanlık Osmanlı Arşivi (BOA), Dahiliye Mektubi Kalemi [DH.MKT.]: 238, 13, $14 / \mathrm{Za} / 1311 ; 240,32,18 / \mathrm{Za} / 1311 ; 303,825,22,8 / \mathrm{Z} / 1321 ; 929,49,27 / \mathrm{Za} / 1322$; $1247,61,13 / \mathrm{Ra} / 1326 ; 35,04 / \mathrm{Ca} / 1312$ 2088, 49, 08/L/1315; 2484, 126, 26/M/1319; 2492, 106, 16/S/1319; 2621, 16, 07/N/1326.

Başbakanlık Osmanlı Arşivi (BOA), Dâhiliye Nezareti Muhaberat-ı Umumiye İdaresi [DH.MUI.]: 33, 34, 29/L/1327.

Başbakanlık Osmanlı Arşivi (BOA), Dahiliye Nezareti Şifre Kalemi [DH.ŞFR.]: 70/87, 29/S/1335; 84/28, 9 Şubat 1334; 488, 31, 26 Ağustos 1331.

Başbakanlık Osmanlı Arşivi (BOA), Dahiliye Nezareti Tesrî̀-i Muâmelât ve Islahat Komisyonu Müteferrik [DH.TMIK.M.]: 206, 38, 27/B/1323.

Başbakanlık Osmanlı Arşivi (BOA), Irade-i Dâhiliye [ID.], 35239, 35239, 1, 12/Ca/1280.

Başbakanlık Osmanlı Arşivi (BOA), Sadâret Mektûbî Kalemi, Mühime Kalemi [A.]MKT.MHM.]: 293, 25, 1/Ş/1280; 553, 9, 27/M/1312.

Başbakanlık Osmanlı Arşivi (BOA), Yıldız Sadaret Hususi Maruzat Evrakı [Y.A.HUS.]: 304, $31,24 / \mathrm{Ca} / 1312$.

Çebi, Sıtkı, Ordu Hatıraları, Ordu Çevre Koruma Vakfı Kültür Yayınları, Ordu, (Tarihsiz).

Demirel, Rüştü, "Yunanistan'dan Anadolu'ya Gelen Türkler (Nüfus Mübadelesi)”, Rüştü Demirel'in Mesleğe ve Hayata Dair Biriktirdikleri, Ordu Serbest Muhasebeci Mali Müşavirler Odası (SMMMO) Yayınları, Samsun, 2018, s. 132-136.

Dizman, İbrahim, Denize Düşen Dağ: Ordu, Heyemola Yayınları, İstanbul, 2008.

Dizman, İbrahim, Ordu'nun XX. Yüzyılı, Ordu Belediyesi Yayınları, Ordu, 2006.

Ekinci, İlhan, “19. Yüzyılda Bir İskele Kasabası Olan Ordu'nun Bataklık ve Sitma ile İmtihanı”, Tarihsel Süreçte Anadolu'da Sitma, (Edt. Şükran Köse - Çağrı Büke Fevzi Çakmak - Eren Akçiçek),Gece Kitaplığı Yayınları, Ankara, 2017, s. 571-602.

Enver, Samsun Mintıkasında Sitma Mücadele Faaliyeti”, Sihhiye Mecmuası, C.5, S. 31-32, 1922, s. 1447-1453.

Ertaş, Mehmet Yaşar - Fatma Yıldız, “19. Yüzyıl'da Anadolu'da Sıtmanın Görüldüğü Yerler ve Alınan Önlemler”, Tarihsel Süreçte Anadolu'da Sitma, (Edt. Şükran Köse-Çağrı Büke-Fevzi Çakmak-Eren Akçiçek), Gece Kitaplığı Yayınları, Ankara, 2017, s. 223245.

Güvenkaya, Ahmet Cevat, Fatsa'nın Tarihçesine Dair Notlar, (Basım yeri ve tarihi mevcut değil).

Hot, İnci, "Türkiye'de Tifüs ile Mücadele", 38. Uluslararası Tip Tarihi Kongresi Bildiri Kitabl, (Ed. Nil Sarı, Ali Haydar Bayat, Yeşim Ülman ve Mary Işın), C. III, Türk Tarih Kurumu Yayınları, Ankara, 2005, s. 1513-1516. 
Hot, İnci, Sihhiye Mecmuasına Göre Ülkemizde Bulaşıcı Hastalıklarla Mücadele (19131996), İstanbul Üniversitesi Sağlık Bilimleri Enstitüsü Deontoloji ve Tip Tarihi Anabilim Dalı, (Yayımlanmamış Doktora Tezi), İstanbul 2001.

Hulûsi Behçet, Frengi Tarihi ve Geçirdiği Evreler [Üniversite Konferanslarl (1935-1936)], C. 1, İstanbul Üniversitesi Yayınları, İstanbul 1937.

İpek, Nedim, “Trabzon'da Kolera (1892-1895), Trabzon ve Çevresi Uluslararası Tarih- DilEdebiyat Sempozyumu (3-5 Mayıs 2001), C. 1, Trabzon Valiliği Yayınları, Trabzon, 2002, s. 399-411.

İpek, Nedim, Imparatorluktan Ulus Devlete Göçler, Serander Yayınları, Trabzon, 2006.

Kılıç, Orhan, "Eskiçağdan Yeniçağa Sitma", Tarihsel Süreçte Anadolu'da Sitma, (Edt. Şükran Köse - Çağrı Büke - Fevzi Çakmak - Eren Akçiçek), Gece Kitaplığı Yayınları, Ankara, 2017, s. 117-159.

Lennep, Henry John Van, Travels in Little-Known Parts of Asia Minor, London, J. Murray by Published, London, 1870.

Lermioğlu, Muzaffer, Akçaabat-Akçaabat Tarihi ve Birinci Genel Savaş-Hicret Hatıraları, Kardeşler Basımevi, İstanbul 1949.

Meclis-i Ayan Zabıt Ceridesi, III/II, Türkiye Büyük Millet Meclisi Basımevi, Ankara, 1990.

Mehmet Ali Kuntman, Tabur Tabibi Derviş Bey (Tabip Binbaşı Mehmet Derviş Kuntman'ın Harp Hatıralarl), Paraf Yayınları, İstanbul, 2011.

Nikiforuk, Andrew, Mahşerin Dördüncü Atllsı (Salgın ve Bulaşıcı Hastalıkların Tarihi), (Çev. Selahattin Erkanlı), İletişim Yayınları, İstanbul 2001.

Özdemir, Hikmet, Salgın Hastalıklardan Ölümler (1914-1918), Türk Tarih Kurumu Yayınları, Ankara, 2005.

Özel, Oktay, "Muhacirler, Yerliler ve Gayrimüslimler, Osmanlı'nın Son Devrinde Orta Karadeniz'de Toplumsal Uyumun Sınırları Üzerine Bazı Gözlemler”, Tarih ve Toplum (Yeni Yaklaşımlar), S. 5, Bahar 2007, s. 113-146.

Özel, Sabahattin, Milli Mücadelede Trabzon, Türk Tarih Kurumu Yayınları, Ankara, 1991.

Özer, Sevilay, '“I. Dünya Savaşı’nda Osmanlı Devleti'nde Tifüs”, Belleten, C. LXXX, S.287, Nisan 2016, s. 219-260.

Özer, Sevilay, "II. Dünya Savaşı Yıllarında Anadolu'da Sitma”, Tarihsel Süreçte Anadolu'da Sitma, (Editör: Şükran Köse ve diğerleri), Gece Kitaplığı, Ankara, 2017, s. 463-490.

Özer, Sevilay, "II. Dünya Savaşı Yıllarında İstanbul'da Tifüs", Çağdaş Türkiye Tarihi Araştırmaları Dergisi, C. XV, S. 30, Bahar 2015, s. 171-201.

Özer, Sevilay, “Türkiye'de Trahomla Mücadele”, Atatürk Yolu Dergisi, S.54, Bahar 2014, s. 121-152.

Özkara, Kemal, Reşadiye Caddesi, Güneş Ofset Matbaacılık, Fatsa, 2002.

Pala, Hikmet, Ordu Tarihinde Olaylar ve Insanlar, Gece Kitaplığı, Ankara, 2015.

Sağlam, Tevfik Salim, Büyük Harpte Üçüncü Orduda Sihhi Hizmete Dair Küçük Bir Hülasa, Askerî Tıbbiye Matbaası, İstanbul, 1940.

Sağllk Hizmetlerinde 50 Yll, Sağlık ve Sosyal Yardım Bakanlığı Yayınları, Ayyıldız Matbaası, Ankara, 1973. 
Serbestoğlu, İbrahim, “Kırım Savaşı Sonrasında Samsun'da Göç ve Göçmen Sorunu”, Geçmişten Geleceğe Samsun, (Edt. Cevdet Yılmaz), C. 1, Samsun Büyükşehir Belediyesi Kültür Daire Başkanlığı Yayını, Samsun, 2006, s. 83-97.

Serbestoğlu, İbrahim, Bir Taşra Şehrinde Tanzimat ve Modernleşme: Canik Sancağı (18631865), Huzur Ciltevi, Malatya, 2015.

Sert, Gürkan - Emre Dölen, “Osmanlı'dan Cumhuriyet'e Devlet Kinini”, Osmanlı Bilimi Araştırmaları, C. XIV, S. 2, 2013, s. 69-86.

Sihhiye Mecmuası Fevkalade Nüshası (Dr. Refik Saydam'ın Aziz Hatırasina), C. 17, S. 104, Sihhat ve İçtimai Muavenet Vekâleti Yayınları, Ulusal Matbaa, Ankara, 1942.

Süslü, Azmi, Ermeniler ve 1915 Tehcir Olayl, Yüzüncü Yıl Üniversitesi Yayınları, Ankara, 1990.

Şehsuvaroğlu, Bedi N., "Tarihi Kolera Salgınları ve Osmanlı Türkleri”, İstanbul Tıp Fakültesi Mecmuası, C. 17, S. 2, İstanbul, 1954, s. 282-306.

Temel, Mehmet, Atatürk Döneminde Bulaşıcı ve Salgın Hastalıklarla Mücadele, Nehir Yayınları, İstanbul, 2008.

Tevfik Salim, "333 Senesinde Üçüncü Ordu Mıntıkasında Yapılacak Emrâz-1 Sâriye Mücadelesi Hakkında Proje”, Sihhiye Mecmuası, Yı1: 4-5, S. 11-12, 1917, s. 10691101.

Toprak, Zafer, "İstanbul'da Fuhuş ve Zührevi Hastalıklar (1914-1933)", Tarih ve Toplum, C. 7, S. 39, Mart 1987, s. 31-40.

Trabzon Vilayet Salnamesi (1878).

Trabzon Vilayeti Salnamesi (1904), C. XXII, Haz. Kudret Emiroğlu, Trabzon İli ve İlçeleri Eğitim, Kültür ve Sosyal Yardımlaşma Vakfı Yayınları, Ankara, 2009.

Tuğluoğlu, Fatih, "Türkiye'de Sitma Mücadelesi (1924-1950)”, Türkiye Parazitoloji Dergisi, C. 32 , S. 4, 2008, s. 351-359.

Türkiye Cumhuriyeti Devlet Ylllı̆̆ (1925-1926), Matbaa-yı Amire, İstanbul, 1926.

Türkiye Cumhuriyeti Devlet Yılliğl (1928-1929), Devlet Matbaas1, İstanbul, 1929.

“Umumi Hifzı's-Sihha Kanunu”, Sihhıye Mecmuası, C. VI, S. 37-38, Ankara, Nisan-Mayıs 1930, 405-479.

Unat, Ekrem Kadri, “Osmanlı İmparatorluğunda İnsanın Bulaşıcı Hastalıklarına Karşı Yapılan Koruyucu Aş1lar”, Dirim, C. 1-12, S. 53, İstanbul, s. 360-369

Unat, Ekrem Kadri, "Osmanlı İmparatorluğunda İnsanın Bulaşıcı Hastalıklarına Karşı Yapılan Koruyucu Aş1lar”, Dirim, C. 11-12, S. 53, İstanbul, s. 366-370.

Yıldırım, Nuran, “Tanzimat'tan Cumhuriyet'e Koruyucu Sağlık Uygulamaları”, Tanzimat'tan Cumhuriyet'e Türkiye Ansiklopedisi, C. 5, İletişim Yayınları, İstanbul, 1985, s. 13191338.

Yıldız, Adnan, Osmanlı Belgelerinde Ordu, Ordu Valiliği Yayınları, İstanbul, 2013.

Yılmaz, Özgür, "1864 Kafkas Göçü Hakkında Bir Rapor”, Mavi Atlas (Gümüşhane Üniversitesi Edebiyat Fakültesi Dergisi, S. 3, 2014, s. 133-155.

Zürcher, Eric Jan, "Between Death and Desertion: The Experience of The Ottoman Soldier in World War I", Turcica, V. 28, 1996, p. 235-258. 